\title{
ANALISIS KOMPARASI INDEKS ISLAMIC SOCIAL REPORTING PERUSAHAAN PERBANKAN SYARIAH DAN PERUSAHAAN GO PUBLIK YANG LISTING DI JAKARTA ISLAMIC INDEX
}

\author{
Citra Indah Merina dan Verawaty \\ citra@binadarma.ac.id; verawaty@binadarma.ac.id \\ Universitas Bina Darma
}

\begin{abstract}
Islamic Social Index Reporting (ISR) is an index that measures the level of social disclosure that according to Islamic principles presented in the company's annual report. This research is aimed to compare the quality of corporate social reporting between the two groups of samples, namely the Islamic banking companies and companies listed in the Jakarta Islamic Index (JII) by using ISR index. This study uses a statistical test Mann Whitney test to compare based on six criteria; Funding and Investment, Products and Services, Employees, Community, Environment, and Corporate Governance between those two groups. The result of this study indicates that the Islamic banking company revealed more based on ISR index than the companies listing in the JII with exception for products and services where the value of first and second group is only slightly in $15.76 \%$. The research proves empirically that the disclosures made by the company that actually operates with the sharia concept as Islamic banking companies are indeed better meet the ISR index than conventional companies listing in the JII.
\end{abstract}

Keywords: Finance and Investment, Products/Services, Employee, Society, Environment, Corporate Governance, Mann Whitney Test

\section{PENDAHULUAN}

Secara konvensional pengungkapan tanggung jawab sosial bagi para pengguna laporan perusahaan termasuk investor adalah suatu hal yang bisa menjadi pertimbangan untuk membuat keputusan berinvestasi karena dari pengungkapan tersebut para pengguna laporan perusahaan bisa mengetahui tindakan apa saja yang dilakukan perusahaan untuk meningkatkan kualitas hidup masyarakat dan lingkungan di sekitarnya. Investor-investor muslim dan para pengguna laporan perusahaan muslim lainnya, menginginkan pengungkapan sosial secara syariah, yaitu mengenai apakah operasional perusahaan sesuai dengan syariah Islam. Apabila perusahaan tempat mereka berinvestasi ataupun terkait kegiatan usaha sesuai dengan syariah, mereka bisa mendapatkan kepuasan spiritual karena sesuai dengan apa yang diyakini sebagai investor muslim.

Untuk menilai pengungkapan sosial perusahaan yang sesuai dengan syariah Islam, dikenal suatu indeks yang disebut sebagai Islamic Social Reporting (ISR). Indeks ISR adalah suatu indeks yang mengukur tingkat pengungkapan sosial yang sesuai prinsip syariah yang disampaikan perusahaan pada laporan tahunannya. Indeks ISR ini merupakan tolak ukur pelaksanaan tanggung jawab sosial perbankan syariah yang berisi kompilasi item-item standar Corporate Social Responsibility (CSR) yang ditetapkan oleh AAOIFI (Accounting and Auditing Organization for Islamic Financial Institutions) yang kemudian dikembangkan lebih lanjut oleh para peneliti mengenai item-item CSR yang diungkapkan oleh suatu entitas Islam.

Sesuainya indeks ISR untuk entitas Islam karena mengungkapkan hal-hal yang berkaitan dengan prinsip Islam seperti transaksi yang sudah terbebas dari unsur riba, 
spekulasi dan gharar, serta mengungkapkan zakat, status kepatuhan syariah serta aspekaspek sosial seperti sodaqoh, waqof, qordul hasan, sampai dengan pengungkapan peribadahan di lingkungan perusahaan. Indeks ISR berdasarkan enam kategori; Pendanaan dan Investasi, Produk dan Jasa, Karyawan, Masyarakat, Lingkungan, dan Tata Kelola Perusahaan.

Othman et al. (2009), mengembangkan indeks pengungkapan yang relevan dengan hal-hal yang telah disebutkan sebelumnya pada Islamic Social Reporting (ISR) Index. ISR pertama kali dikemukan oleh Haniffa (2002), lalu dikembangkan secara lebih ektensif oleh Othman et al. (2009), di Malaysia. Haniffa (2002), mengungkapkan bahwa adanya keterbatasan dalam pelaporan sosial konvensional sehingga ia mengemukakan kerangka konseptual ISR berdasarkan ketentuan syariah yang tidak hanya membantu pengambilan keputusan bagi pihak muslim melainkan juga untuk membantu perusahaan dalam melakukan pemenuhan kewajiban sosial kepada masyarakat sekaligus memberikan kepuasan spiritual bagi investornya.

Penelitian mengenai ISR sebenarnya sudah banyak dilakukan. Maulida, dkk (2014) menganalisis faktor-faktor mempengaruhi ukuran perusahaan, profitabilitas dan kinerja lingkungan terhadap pengungkapan ISR pada perusahaan-perusahaan yang terdaftar pada Jakarta Islamic Index (JII). Ayu (2010) mencari tahu pengaruh profitabilitas, ukuran perusahaan, dan jenis industri terhadap tingkat pengungkapan ISR pada perusahaan-perusahaan yang terdaftar pada JII. Raditya (2012) melakukan penelitian atas variabel profitabilitas, ukuran perusahaan, jenis industri dan juga menambah variabel baru sukuk dan umur perusahaan untuk dianalisis pengaruhnya terhadap pengungkapan ISR pada perusahaan yang masuk Daftar Efek Syariah (DES) periode 2009-2010. Widiawati dan Raharja (2012) yang mencari tahu pengaruh ukuran perusahaan, profitabilitas, tipe industri dan jenis bank terhadap ISR perusahaan yang terdapat pada DES. Putri (2014) mencari tahu pengaruh ukuran perusahaan, profitabilitas, tipe industri dan surat berharga terhadap ISR perusahaan yang terdaftar pada Index Saham Syariah Indonesia (ISSI). Namun semua penelitian tersebut hanya mencari faktorfaktor yang mempengaruhi pengungkapan ISR saja. Penelitian ini berbeda dengan penelitian yang telah dilakukan sebelumnya.

Penelitian ini akan membandingkan kualitas pengungkapan berdasarkan indeks ISR antara dua kelompok sampel, yaitu perusahaan perbankan syariah dan perusahaan yang listing di Jakarta Islamic Index (JII). Perbankan syariah merupakan bank yang beroperasi sesuai dengan prinsip-prinsip syariah Islam yang dalam operasinya mengikuti ketentuan-ketentuan syariah Islam, khususnya yang menyangkut tata cara bermuamalah secara Islam. Adapun JII merupakan salah satu produk pasar modal syariah di Bursa Efek Indonesia (BEI) yang menggambarkan kinerja saham syariah di Indonesia. Saham-saham syariah yang masuk dalam JII adalah saham-saham yang sudah lulus penyeleksian kriteria dari Otoritas Jasa Keuangan (OJK) dan BEI. Perusahaan-perusahaan yang terdaftar dalam JII sudah bisa dipastikan memiliki kegiatan operasional yang tidak bertentangan dengan prinsip-prinsip syariah, sehingga besar kemungkinan banyak investor muslim ataupun pihak berkepentingan muslim lainnya yang berinvestasi dan terkait kegiatan usaha dengan perusahaan tersebut.

Dalam konteks pemikiran praktis, pengungkapan yang dilakukan oleh perusahaan yang benar-benar beroperasi dengan konsep syariah seperti perbankan syariah tentu akan lebih memenuhi indeks ISR dibandingkan perusahaan konvensional non perbankan syariah seperti perusahaan-perusahaan konvensional yang listing di JII. Hal ini tentu harus dibuktikan secara empiris sehingga hipotesis penelitian adalah bahwa perusahaan perbankan syariah akan mengungkapkan indeks ISR yang lebih baik dibandingkan dengan perusahaan listing di JII. 
Penelitian ini menggunakan pengujian statistik Mann Whitney Test untuk membandingkan enam kategori pada indeks ISR antar kedua kelompok sampel tersebut. Penelitian ini merupakan penelitian pertama yang membandingkan kualitas ISR dalam dua kelompok yang berbeda karena penelitian-penelitian sebelumnya selalu menghubungkan faktor-faktor apa yang mempengaruhi pengungkapan ISR saja jadi penelitian ini bersifat eksploratif.

\section{TINJAUAN PUSTAKA ISR (Islamic Social Reporting)}

Sejalan dengan makin meningkatnya pelaksanaan Corporate Social Responsibility (CSR) dalam dunia bisnis, maka semakin meningkat pula keinginan untuk membuat pelaporan sosial atau yang sering disebut dengan social reporting. Banyak pendapat yang menjelaskan mengenai pengungkapan social reporting. Social reporting merupakan perluasan dari sistem pelaporan keuangan yang merefleksikan perkiraan yang baru dan yang lebih luas dari masyarakat sehubungan dengan peran komunitas bisnis dalam perekonomian Hannifa (2002).

Adanya konsep tanggung jawab sosial dalam Islam maka meningkatkan pula keinginan untuk membuat pelaporan ataupun pengungkapan sosial yang bersifat syariah. Hanya saja sampai saat ini belum ada standar pelaporan tanggung jawab sosial secara syariah yang bisa dijadikan patokan standar secara internasional. AAOIFI (Accounting and Auditing Organization for Islamic Financial Reporting) sebagai organisasi yang mengembangkan akuntansi dan auditing bagi lembaga keuangan syariah di tingkat keuangan syariah, akan tetapi standar AAOIFI tersebut tidak dapat dijadikan sebagai suatu standar atas pengungkapan tanggung jawab sosial secara syariah karena tidak menyebutkan keseluruhan item-item terkait pelaporan tanggung jawab sosial yang harus diungkapkan oleh perusahaan.

Salah satu cara untuk menilai pelaporan tanggung jawab sosial perusahaan secara syariah yaitu dengan menggunakan indeks Islamic Social Reporting (ISR). Menurut Haniffa (2002), ISR adalah perpanjangan pelaporan sosial yang meliputi tidak hanya harapan dewan pengurus atas pandangan masyarakat terhadap peran perusahaan dalam ekonomi, tetapi juga memenuhi perspektif spiritual untuk pengguna laporan yang muslim. ISR bertujuan memdemonstrasikan akuntabilitas kepada Allah SWT dan komunitas. ISR juga bertujuan meningkatkan transparasi dari aktivitas bisnis dengan menyediakan informasi yang relevan dalam memenuhi kebutuhan spiritual dari pengguna laporan perusahaan yang muslim. Selain itu, indeks ISR juga menekankan pada keadilan sosial terkait pelaporan mengenai lingkungan, kepentingan minoritas, dan karyawan.

ISR sebenarnya merupakan kumpulan indeks pelaporan tanggung jawab sosial yang sudah ditetapkan oleh AAOFII yang sesuai dengan syariah dan kemudian dikembangkan oleh masing-masing peneliti berikut (Haniffa, 2002; Maali et al., 2006; Ousama dan Fatima, 2006; dan Othman et al., 2009). Indeks ISR yang dirancang oleh Othman et al. (2009) adalah pengembangan indeks yang diadaptasi dari Haniffa (2002). Haniffa mengembangkan laporan Islam berdasarkan enam kriteria: Pendanaan dan Investasi, Produk dan Jasa, Karyawan, Masyarakat, Lingkungan, dan Tata Kelola Perusahaan.

Dalam penelitian ini, penulis menggunakan indeks ISR yang dirancang oleh Othman et al. (2009), penulis akan melakukan sedikit penyelesaian atas indeks-indeks tersebut dengan menyesuaikan indeks-indeks yang tidak bisa diterapkan di Indonesia, sama dengan yang telah dilakukan oleh penelitian sebelumnya yaitu Ayu (2010) dan Raditya (2012). Berikut adalah enam kriteria pengungkapan dalam kerangka indeks ISR yang digunakan dalam penelitian ini: 
1. Pendanaan dan Investasi

a. Riba (interest-free)

Riba berasal dari bahasa Arab yang berarti tambahan (Al-Ziyadah), berkembang (An-Nuwuw), meningkat (Al-Irtifa'), dan membesar (Al-'uluw). Menurut Widiawaty dan Raharja (2012) mengenai masalah riba sebagai setiap penambahan yang diambil tanpa adanya suatu penyeimbang atau pengganti ( 'iwad) yang dibenarkan syariah.

b. Gharar (ketidakpastian)

Terjadi ketika terdapat incomplete information antara kedua pihak yang bertransaksi dalam hal kuantitas, kualitas, harga, waktu penyerahan dan akad. Salah satu contoh dari transaksi yang mengandung gharar adalah transaksi lease and purchase (sewa-beli) karena adanya ketidakpastian dalam akad yang diikrarkan antara kedua pihak.

c. Zakat

Zakat adalah kewajiban bagi seluruh umat muslim atas harta benda yang dimiliki ketika telah mencapai nisab. Zakat tidaklah sama dengan donasi, sumbangan, dan shadaqah. Zakat memiliki aturan yang jelas mengenai harta yang dizakatkan, batasan harta yang terkena zakat, cara penghitungannya, dan siapa yang boleh menerima harta zakat sesuai apa yang telah diatur oleh Allah SWT.

d. Kewajiban atas keterlambatan pembayaran piutang dan penghapusan piutang tak tertagih

Penangguhan atau penghapusan utang harus dilakukan dengan adanya penyelidikan terlebih dahulu kepada pihak debitur terkait ketidak mampuannya dalam pembayaran piutang. Penangguhan atau penghapusan utang merupakan suatu bentuk sikap tolong-menolong yang dianjurkan di dalam Islam.

e. Current Value Balance Sheet

Othman et al. (2009), terdapat satu indeks pengungkapan lainnya yaitu current value balance sheet akan tetapi dalam penelitian ini peneliti tidak memasukkannya dalam indeks ISR. Sesuai dengan pendapat Ayu (2010), klasifikasi current value balance sheet menjadi tidak relevan sebagai kriteria pengungkapan karena PSAK masih memberlakukan nilai historis atas nilai-nilai di neraca. Kenyataannya perusahaan di Indonesia berpedoman pada PSAK dan banyak perusahaan yang masih memberlakukan nilai historis atas nilai-nilai di neraca, maka dalam penelitian ini current value balance sheet tidak dimasukkan dalam indeks.

f. Value Added Statement

Value added (nilai tambah) sebagai nilai yang tercipta dari hasil aktivitas perusahaan dan karyawan-karyawan, sedangkan value added statement merupakan pernyataan yang melaporkan perhitungan nilai tambah tersebut serta aplikasi di antara para pemangku kepentingan perusahaan. Istilah value added statement pada dewasa ini diartikan sebagai laporan pertambahan nilai. Di Indonesia, laporan pertambahan nilai belum berkembang seperti ini negaranegara maju. Oleh karena itu, dalam penelitian ini value added statement merujuk pada pernyataan nilai tambah yang ada di dalam laporan tahunan perusahaan.

2. Produk dan Jasa

a. Produk yang ramah lingkungan (green product)

Setiap perusahaan di seluruh dunia diharapkan menghasilkan produk ataupun jasa yang ramah lingkungan sebagai suatu bentuk partisipasi dalam menjaga dan memelihara lingkungan yang kian mengalami kerusakan.

b. Status kehalalan produk 
Pentingnya status kehalalan suatu produk merupakan suatu kewajiban yang harus diungkapkan oleh perusahaan dalam laporan tahunannya kepada seluruh konsumen muslim yang notabenya masyarakat Indonesia sebagian besar adalah pemeluk agama Islam. Status kehalalan suatu produk diketahui setelah mendapatkan sertifikat kehalalan produk dari Majelis Ulama Indonesia (MUI).

c. Kualitas dan keamanan suatu peroduk

Setelah produk dinyatakan halal, hal ini yang juga penting untuk perusahaan dalam mengungkapkan produknya adalah mengenai kualitas dan keamanan produk. Produk yang berkualitas dan aman akan meningkatkan kepercayaan dan loyalitas konsumen terhadap suatu perusahaan. Kualitas dan keamanan suatu produk perusahaan dinyatakan dengan adanya ISO 9000:2000 yang merupakan sertifikat manajemen mutu.

d. Keluhan konsumen/indikator yang tidak terpenuhi dalam peraturan dan kode sukarela (jika ada)

Item pengungkapan selanjutnya adalah mengenai keluhan konsumen atau pelayanan pelanggan. Suatu perusahaan diharapkan tidak hanya berfokus pada produk yang dihasilkan (product-oriented) melainkan memberikan pelayanan terhadap konsumen yang memuaskan (consumer-oriented) dengan menyediakan pusat layanan keluhan konsumen setelah proses jual beli.

3. Karyawan

Menurut Othman dan Thani (2010) memaparkan bahwa masyarakat Islam ingin mengetahui apakah karyawan-karyawan perusahaan telah diperlakukan secara adil dan wajar melalui informasi-informasi yang diungkapkan, seperti upah, karateristik pekerjaan, jam kerja per hari, libur tahunan, jaminan kesehatan dan kesejahteraan, kebijakan terkait waktu dan tepat ibadah, pendidikan dan pelatihan, kesetaraan hak, dan lingkungan kerja.

4. Masyarakat

Item-item pengungkapan dalam kriteria masyarakat yang digunakan dalam penelitian ini adalah sodaqah/donasi, wakaf, qard hassan, sukarelawan dari pihak karyawan, pemberian beasiswa, pemberdayaan kerja bagi siswa yang lulus sekolah/kuliah berupa magang atau praktek kerja lapangan, pengembangan dalam kepemudaan, peningkatan kualitas hidup masyarakat kelas bawah, kepedulian terhadap anak-anak, kegiatan amal/bantuan/kegiatan sosial lain, dan mensponsori berbagai macam kegiatan seperti kesehatan, hiburan, olahraga, budaya, pendidikan dan agama. Haniffa (2002), menerangkan bahwa konsep dasar yang mendasari tema ini adalah ummah, amanah, dan $a d l$. Konsep tersebut menekankan pada pentingnya saling berbagi dan meringankan beban orang lain dengan hal-hal yang telah disebutkan pada item-item pengungkapan di atas. Perusahaan memberikan bantuan dan kontribusi kepada masyarakat dengan tujuan semata-mata untuk meningkatkan pertumbuhan ekonomi dan membantu menyelesaikan permasalahan sosial di masyarakat seperti membantu memberantas buta aksara, memberikan beasiswa, dan lain-lain (Maali et al, 2006 dan Othman dan Thani, 2010).

5. Lingkungan

Bagi seluruh makhluk hidup untuk melindungi lingkungan sekitarnya, konsep yang mendasari tema lingkungan dalam penelitian ini adalah mizan, I'tidal, khilafah, dan akhirah. Konsep tersebut menekankan pada prinsip keseimbangan, kesederhanaan, dan tanggung jawab dalam menjaga lingkungan. Oleh karena itu, informasiinformasi yang berhubungan dengan penggunaan sumber daya dan program-program yang digunakan untuk melindungi lingkungan harus diungkapkan dalam laporan tahunan perusahaan (Othman dan Thani, 2010). 
6. Tata Kelola Perusahaan (Corporate Governance)

Othman dan Thani (2010), perusahaan haruslah mengungkapkan semua aktivitas terlarang seperti praktek monopoli, manipulasi harga, perjudian, dan penimbunan barang yang dibutuhkan dan kegiatan melanggar hukum lainnya. Pengungkapan lainnya yang masuk dalam kriteria Tata Kelola Perusahaan adalah pernyataan status syariah. Ayu (2010), menyatakan bahwa pengungkapan pada pernyataan misi perusahaan harus menyertakan:

a. Pernyataan yang menyatakan bahwa operasi perusahaan telah berdasarkan prinsip syariah.

b. Pernyataan yang menyatakan bahwa tujuan utama perusahaan adalah untuk mencapai barakah (keberkahan) dan al-falah (kesuksesan di dunia dan di akhirat), dengan menekankan bahwa pentingnya keuntungan yang halal.

Apabila perusahaan telah mengungkapkan kedua pernyataan tersebut dapat dikatakan bahwa perusahaan tersebut telah sangat sesuai dengan prinsip syariah. Akan tetapi kedua kriteria ini masih belum terdapat dalam kriteria saham Jakarta Islamic Index (JII), tetapi dalam penelitian ini penulis tetap memasukkan indeks pengungkapan ini untuk mengetahui keberadaan perusahaan yang masuk dalam daftar JII dan yang secara tegas menyatakan bahwa perusahaan tersebut berprinsip syariah.

\section{Penelitian-Penelitian Terdahulu}

Penelitian mengenai Islamic Social Reporting (ISR) dilakukan oleh Maulida, dkk (2014), menganalisis faktor-faktor mempengaruhi ukuran perusahaan, profitabilitas dan kinerja lingkungan terhadap pengungkapan ISR pada perusahaan-perusahaan yang terdaftar pada Jakarta Islamic Index (JII). Hasil penelitian tersebut menunjukkan bahwa ukuran perusahaan, profitabilitas, dan kinerja lingkungan berpengaruh positif terhadap pengungkapan ISR. Penelitian ini juga dilakukan oleh Ayu (2010), yang mencari tahu pengaruh profitabilitas, ukuran perusahaan, dan jenis industri terhadap tingkat pengungkapan ISR pada perusahaan-perusahaan yang terdaftar pada JII. Hasil penelitian tersebut menunjukkan bahwa profitabilitas dan ukuran perusahaan memiliki pengaruh yang signifikan pada tingkat pengungkapan ISR dan jenis industri tidak memiliki pengaruh yang signifikan.

Penelitian ini juga dilakukan oleh Raditya (2012), yang melakukan penelitian atas variabel profitabilitas, ukuran perusahaan, jenis industri dan juga menambah variabel baru sukuk dan umur perusahaan untuk dianalisis pengaruhnya terhadap pengungkapan ISR pada perusahaan yang masuk Daftar Efek Syariah (DES) periode 2009-2010. Penelitian ini juga dilakukan oleh Widiawati dan Raharja (2012), yang mencari tahu pengaruh ukuran perusahaan, profitabilitas, tipe industri dan jenis bank terhadap ISR perusahaan yang terdapat pada DES. Hasil penelitian tersebut menunjukkan bahwa ukuran perusahaan, profitabilitas, tipe industri dan jenis bank ada hubungan positif terhadap ISR. Penelitian ini juga dilakukan oleh Putri (2014), yang mencari tahu pengaruh ukuran perusahaan, profitabilitas, tipe industri dan surat berharga terhadap ISR perusahaan yang terdaftar pada Index Saham Syariah Indonesia (ISSI). Hasil penelitian tersebut menunjukkan bahwa ukuran perusahaan, profitabilitas, tipe industri, dan jenis bank berpengaruh positif terhadap ISR.

Semua penelitian tersebut menjadi referensi penting pada penelitian ini, terutama dalam menjelaskan konsep ISR beserta kriteria atau kriteria indeksnya. Namun semua penelitian tersebut hanya mencari faktor-faktor yang mempengaruhi pengungkapan ISR saja. Penelitian ini berbeda dengan penelitian yang telah dilakukan sebelumnya. Perbedaan signifikan tersebut adalah 1.) Penelitian ini akan membandingkan 
kualitas pengungkapan berdasarkan indeks ISR antara dua kelompok sampel, yaitu perusahaan perbankan syariah dan perusahaan yang listing di Jakarta Islamic Index (JII) dan 2.) Penelitian akan menggunakan pengujian statistik Mann Whitney Test untuk membandingkan enam kriteria pada indeks ISR antar kedua kelompok sampel tersebut, yaitu Pendanaan dan Investasi, Produk dan Jasa, Karyawan, Masyarakat, Lingkungan, dan Tata Kelola Perusahaan.

Motivasi penelitian untuk membandingkan kedua kelompok sampel adalah untuk membuktikan apakah, pengungkapan yang dilakukan oleh perusahaan yang benarbenar beroperasi dengan konsep syariah seperti perbankan syariah tentu akan lebih memenuhi indeks ISR dibandingkan perusahaan konvensional non perbankan syariah seperti perusahaan-perusahaan konvensional yang listing di JII. Hal ini tentu harus dibuktikan secara empiris sehingga hipotesis penelitian adalah bahwa perusahaan perbankan syariah akan mengungkapkan indeks ISR yang lebih baik dibandingkan dengan perusahaan listing di JII.

\section{METODOLOGI PENELITIAN Variabel Penelitian}

Dalam penelitian ini, ukuran yang digunakan untuk menilai tingkat pengungkapan ISR yang telah dilakukan oleh perusahaan yang terdaftar dalam JII menggunakan indeks ISR yang dirancang oleh Othman et al. (2009), dan yang terdapat dalam penelitian Ayu (2010), tetapi tidak sepenuhnya menggunakan indeks tersebut karena penulis akan melakukan sedikit modifikasi atas rancangan indeks tersebut. Penggunaan indeks ISR ini karena penulis ingin mengetahui pengungkapan ISR perusahaan yang sesuai dengan prinsip Islam. Indeks ISR yang dibuat oleh Othman et al. (2009), adalah hasil adaptasi dari penelitian Haniffa (2002). Haniffa (2002), mengembangkan laporan Islam didasarkan pada lima kategori yaitu, Keuangan dan Investasi, Produk, Karyawan, Masyarakat, dan Lingkungan. Pengembangan dan memodifikasi hasil penelitian Haniffa (2002), yang telah dilakukan oleh Othman et al. (2009), telah mengidentifikasikan 43 item indeks pengungkapan dan dikategorikan menjadi enam, yaitu Keuangan dan Investasi, Produk atau Jasa, Karyawan, Lingkungan, dan Tata Kelola Perusahaan.

Penggunaan indeks ISR yang dirancang oleh Othman et al. (2009), ini dilakukan pada penelitian Ayu (2010) dan Raditya (2012) yang juga membagi ISR menjadi enam kategori dengan total pengungkapan 43item indeks pengungkapan. Nilai terbesar (skor) yang dapat diperoleh setiap tahunnya dari laporan pengungkapan perusahaan adalah 43 dan yang terkecil adalah nol (0).

Metode pemberian nilai (skor) pada penelitian ini sama dengan pada penelitian Othman et al. (2009), Ayu (2010), dan Raditya (2012), yaitu pemberian nilai skor terhadap content analysis. Pemberian nilai pada content analysis yang terdiri dari 43 item indeks ISR tersebut tidak diukur untuk berapa kali jumlah kejadian untuk masing-masing item diungkapkan dalam satu periode tahunan, tetapi minimal satu kali pengungkapan indeks ISR dalam bentuk apapun telah diungkapkan, maka item tersebut dianggap telah ada dan diberi nilai (skor) 1. Apabila item tersebut tidak ditemukan diungkapan maka item tersebut akan diberikan nilai (skor) 0. Penilaian item indeks ini akan diidentifikasi dan dikumpulkan dari analisis atau penemuan dari laporan tahunan perusahaan. Nilai skor akan dijumlah secara keseluruhan. Selain itu nilai skor juga akan dijumlah tiap kategori dan tiap perusahaan untuk mengetahui pengungkapan yang mana yang paling banyak diungkapkan oleh perusahaan dan perusahaan mana yang memberikan pengungkapan ISR paling banyak. Berikut ini tabel Islamic Social Reporting (ISR) Index: 
Islamic Social Reporting (ISR) Index

\begin{tabular}{|c|c|}
\hline $\mathbf{A}$ & Pendanaan dan Investasi \\
\hline 1 & Riba \\
\hline 2 & Gharar \\
\hline 3 & $\begin{aligned} \text { Zakat: } & \\
- & \text { Metode yang digunakan } \\
- & \text { Jumlah zakat } \\
- & \text { Penerima manfaat }\end{aligned}$ \\
\hline 4 & $\begin{array}{l}\text { Kewajiban atas keterlambatan pembayaran piutang dan penghapusan piutang tak } \\
\text { tertagih }\end{array}$ \\
\hline 5 & Current Value Balance Sheet (CVBS) \\
\hline 6 & Value Added Statement (VAS) \\
\hline $\mathbf{B}$ & Produk dan Jasa \\
\hline 7 & Produk yang ramah lingkungan \\
\hline 8 & Status kehalalan produk \\
\hline 9 & Kualitas dan keamanan suatu produk \\
\hline 10 & $\begin{array}{l}\text { Keluhan konsumen/indikator yang tidak terpenuhi dalam peraturan dan kode } \\
\text { sukarela (jika ada) }\end{array}$ \\
\hline $\mathbf{C}$ & Karyawan \\
\hline 11 & $\begin{array}{ll}\text { Sifat pekerjaan: } \\
- & \text { Jam kerja } \\
- & \text { Liburan } \\
- & \text { Manfaat lain } \\
\end{array}$ \\
\hline 12 & Pendidikan dan pelatihan/pengembangan sumber daya manusia \\
\hline 13 & Kesempatan yang sama \\
\hline 14 & Keterlibatan karyawan \\
\hline 15 & Kesehatan dan keselamatan kerja \\
\hline 16 & Lingkungan kerja \\
\hline 17 & $\begin{array}{l}\text { Karyawan khusus kelompok lain (cacat, mantan narapidana, mantan pecandu } \\
\text { narkoba) }\end{array}$ \\
\hline 18 & $\begin{array}{l}\text { Eselon yang lebih tinggi di perusahaan melakukan shalat berjamaah dengan para } \\
\text { manajer tingkat yang lebih rendah dan menengah }\end{array}$ \\
\hline 19 & $\begin{array}{l}\text { Karyawan muslim diizinkan untuk melakukan shalat wajib mereka selama waktu } \\
\text { dan puasa tertentu ramadhan pada hari kerja mereka }\end{array}$ \\
\hline 20 & Tempat yang tepat ibadah bagi karyawan \\
\hline $\mathbf{D}$ & Masyarakat \\
\hline 21 & Saddaqa/ donasi \\
\hline 22 & Wakaf \\
\hline 23 & Qardhassan \\
\hline 24 & Biaya sukarela \\
\hline 25 & $\begin{array}{ll}\text { Pendidikan: } \\
- & \text { skema adopsi sekolah } \\
- & \text { beasiswa } \\
\end{array}$ \\
\hline 26 & Lulusan kerja \\
\hline 27 & Generasi muda \\
\hline 28 & Kemiskinan \\
\hline 29 & Kepedulian anak \\
\hline 30 & Amal/hadiah/kegiatan sosial \\
\hline 31 & Mensponsori kesehatan masyarakat/proyek rekreasi/acara budaya \\
\hline
\end{tabular}




\begin{tabular}{|c|c|}
\hline $\mathbf{E}$ & Lingkungan \\
\hline 32 & Konservasi lingkungan \\
\hline 33 & Satwa liar yang terancam punah \\
\hline 34 & Pencemaran lingkungan \\
\hline 35 & Pendidikan lingkungan \\
\hline 36 & Produk lingkungan/proses yang terkait \\
\hline 37 & Audit lingkungan/pernyataan verifikasi independen/pemerintahan \\
\hline 38 & Sistem manajemen lingkungan / kebijakan \\
\hline $\mathbf{F}$ & Tata kelola perusahaan \\
\hline 39 & Status kepatuhan syariah \\
\hline 40 & $\begin{array}{l}\text { Struktur kepemilikan: } \\
-\quad \text { jumlah pemegang saham muslim dan kepemilikan sahamnya }\end{array}$ \\
\hline 41 & Papan struktur-muslim vs non-muslim \\
\hline 42 & $\begin{array}{ll}\text { Kegiatan } & \text { terlarang: } \\
- & \text { praktek monopoli } \\
- & \text { penimbunan barang yang diperlukan } \\
- & \text { manipulasi harga } \\
- & \text { praktek bisnis penipuan } \\
- & \text { judi }\end{array}$ \\
\hline 43 & Kebijakan anti-korupsi \\
\hline
\end{tabular}

\section{Populasi dan Sampel Penelitian}

Populasi penelitian adalah perusahaan yang menjalankan kegiatannya secara syariah atau perusahaan yang kegiatan operasionalnya tidak bertentangan dengan konsep syariah. Sampel penelitian dibagi menjadi dua, yaitu perusahaan perbankan syariah dan perusahaan yang listing di Jakarta Islamic Index (JII). Yang termasuk kelompok pertama, yaitu PT. Bank BCA Syariah, PT. Bank BNI Syariah, PT. Bank BRI Syariah, PT. Bank Jabar Banten Syariah, PT. Bank Maybank Syariah Indonesia, PT. Bank Muamalat Indonesia, PT. Bank Panin Syariah, PT. Bank Syariah Bukopin, PT. Bank Syariah Mandiri, PT. Bank Syariah Mega Indonesia, dan PT. Bank Victoria Syariah. Adapun yang termasuk kelompok kedua, yaitu Astra Agro Lestari Tbk., Adaro Energy Tbk., AKR Corporindo Tbk., Astra International Tbk., Alam Sutera Realty Tbk., Global Mediacom Tbk., Bumi Serpong Damai Tbk. Charoen Pokphand Indonesia Tbk., Ciputra Development Tbk., XL Axiata Tbk., Indofood CBP Sukses Makmur Tbk., Vale Indonesia Tbk., Indofood Sukses Makmur Tbk., Indocement Tunggal Prakarsa Tbk., Indo Tambangraya Megah Tbk., Jasa Marga (Persero) Tbk.,Kalbe Farma Tbk., Lippo Karawaci Tbk., PP London Sumatra Indonesia Tbk., Media Nusantara Citra Tbk., Matahari Putra Prima Tbk., Perusahaan Gas Negara (Persero) Tbk., Tambang Batubara Bukit Asam (Persero) Tbk., Siloam International Hospital Tbk., Semen Indonesia (Persero) Tbk., Summarecon Agung Tbk., Telekomunikasi Indonesia (Persero) Tbk., United Tractors Tbk. Unilever Indonesia Tbk., dan Wijaya Karya (Persero) Tbk.

Penentuan sampel dari setiap kelompok dengan menggunakan metode purposive sampling. Kriteria khusus untuk kelompok pertama, yaitu:

1. Perusahaan memiliki corporate website sampai dengan Juni 2016 dan dalam kondisi aktif atau tidak dalam perbaikan (maintenance)

2. Perusahaan mempublikasikan annual report tahun 2015

Adapun kriteria untuk kelompok kedua, yaitu:

1. Terdaftar dalam Jakarta Islamic Index (JII) tahun 2015 
2. Perusahaan memiliki corporate website sampai dengan Juni 2016 dan dalam kondisi aktif atau tidak dalam perbaikan (maintenance)

3. Perusahaan mempublikasikan annual report tahun 2015

\section{Tehnik Pengumpulan Data}

Data dikumpulkan melalui observasi dengan media internet terhadap ketersediaan annual report pada dua kelompok sampel yang akan dianalisis secara komparatif berdasarkan Islamic Social Reporting (ISR) Index. Annual report diperoleh dari Jakarta Islamic Index (JII) atau website perusahaan. Selain itu, tentunya data sekunder lainnya adalah berbagai sumber yang menjadi tinjauan pustaka dalam membangun hipotesis dan sekaligus mengujinya, antara lain buku-buku teks, artikel-artikel ilmiah ataupun populer, koran, serta internet.

\section{Analisis Data}

Penelitian ini menggunakan pengujian statistik Mann Whitney Test untuk membandingkan berdasarkan enam kriteria; Pendanaan dan Investasi, Produk dan Jasa, Karyawan, Masyarakat, Lingkungan, dan Tata Kelola Perusahaan antar kedua kelompok sampel, yaitu perusahaan perbankan syariah dan perusahaan yang listing di Jakarta Islamic Index (JII). Metoda analisis ini dipilih karena data yang digunakan anova oneway dengan menggunakan rank (indeks) dan sampel berasal dari populasi yang sama. Uji ini mirip dengan uji anova pada data parametrik hanya saja tidak dipenuhi anggapan kenormalan (tanpa uji asumsi klasik) dari data.

\section{HASIL DAN PEMBAHASAN}

Hasil survei telah dilakukan pada periode penelitian terkait populasi penelitian, yaitu perusahaan yang menjalankan kegiatannya secara syariah atau perusahaan yang kegiatan operasionalnya tidak bertentangan dengan konsep syariah, yaitu perusahaan perbankan syariah (11 perusahaan) dan perusahaan yang listing di Jakarta Islamic Index (30 perusahaan). Hasil survei juga menunjukkan adanya disparitas praktek pengungkapan informasi keuangan Islamic Social Reporting (ISR) Index. Kualitas pengungkapan dilakukan oleh kedua kelompok sampel sangat bervariasi.

Hasil survei (observasi) terhadap kelompok perusahaan perbankan syariah, kriteria paling tinggi adalah Masyarakat. Dalam kriteria ini dinilai pelaporan terkait saddaqa/ donasi, wakaf, qardhassan, biaya sukarela, pendidikan: skema adopsi sekolah dan beasiswa, lulusan kerja, generasi muda, kemiskinan, kepedulian anak, amal/hadiah/kegiatan sosial, dan mensponsori kesehatan masyarakat/proyek rekreasi/acara budaya. Fitur pendidikan dan amal/hadiah/kegiatan sosial paling banyak dilaporkan di laporan keuangan (annual report) perusahaan.

Dari keseluruhan kriteria, perusahaan yang paling banyak menyajikan ISR Index adalah PT. Bank BNI Syariah dan PT. Bank Syariah Mandiri dengan nilai skor 32. Adapun perusahaan yang paling sedikit menyajikan ISR Index adalah PT. Bank Syariah Mega Indonesia dengan nilai skor 14. Secara rerata, nilai skor ISR Index untuk semua perusahaan perbankan syariah adalah 25 . Secara keseluruhan jumlah skor yang dicapai kelompok ini dibandingkan dengan skor maksimal yang bisa dicapai adalah 57.72\%.

Dari kategori A atau Pendanaan dan Investasi, terdapat tujuh perusahaan yang paling banyak menyajikan, yaitu PT. Bank BCA Syariah, PT. Bank BNI Syariah, PT. Bank BRI Syariah, PT. Bank Muamalat Indonesia, PT. Bank Panin Syariah, PT. Bank Syariah Mandiri, dan PT. Bank Syariah Mega Indonesia dengan nilai 5 dari total skor maksimal 6. Dari kategori B atau Produk dan Jasa, terdapat tiga perusahaan yang paling banyak menyajikan, yaitu PT. Bank BCA Syariah, PT. Bank BNI Syariah, dan PT. Bank 
BRI Syariah dengan nilai 4 dari total skor maksimal 4. Dari kategori $C$ atau Karyawan, terdapat enam perusahaan yang paling banyak menyajikan, yaitu PT. Bank BNI Syariah, PT. Bank Jabar Banten Syariah, PT. Bank Muamalat Indonesia, PT. Bank Panin Syariah, PT. Bank Syariah Bukopin, dan PT. Bank Syariah Mandiri dengan nilai 6 dari total skor maksimal 10. Dari kategori D atau Masyarakat, terdapat satu perusahaan yang paling banyak menyajikan, yaitu PT. Bank BNI Syariah dengan nilai 11 dari total skor maksimal 11. Dari kategori E atau Lingkungan, terdapat satu perusahaan yang paling banyak menyajikan, yaitu PT. Bank Muamalat Indonesia dengan nilai 6 dari total skor maksimal 7. Dari kategori F atau Tata Kelola Perusahaan, semua perusahaan mendapat nilai 2 dari total skor maksimal 5.

Adapun berdasarkan hasil survei (observasi) terhadap kelompok perusahaan yang listing di Jakarta Islamic Index (JII), kriteria yang paling tinggi adalah Karyawan. Dalam kriteria ini dinilai pelaporan terkait sifat pekerjaan (jam kerja, liburan, manfaat lain), pendidikan dan pelatihan/pengembangan sumber daya manusia, kesempatan yang sama, keterlibatan karyawan, kesehatan dan keselamatan kerja, lingkungan kerja, karyawan khusus kelompok lain (cacat, mantan narapidana, mantan pecandu narkoba), eselon yang lebih tinggi di perusahaan melakukan shalat berjamaah dengan para manajer tingkat yang lebih rendah dan menengah, karyawan muslim diizinkan untuk melakukan shalat wajib mereka selama waktu dan puasa tertentu ramadhan pada hari kerja mereka, dan tempat yang tepat ibadah bagi karyawan. Fitur pendidikan dan pelatihan/pengembangan sumber daya manusia, kesehatan dan keselamatan kerja, serta lingkungan kerja paling banyak dilaporkan di laporan keuangan (annual report) perusahaan.

Dari keseluruhan kriteria, perusahaan yang paling banyak menyajikan ISR Index adalah Astra International Tbk dengan nilai skor 25. Adapun perusahaan yang paling sedikit menyajikan ISR Index adalah Bumi Serpong Damai Tbk dengan nilai skor 11. Secara rerata, nilai skor ISR Index untuk semua perusahaan yang listing di JII adalah 17. Secara keseluruhan jumlah skor yang dicapai kelompok ini dibandingkan dengan skor maksimal yang bisa dicapai adalah $39.46 \%$.

Dari kategori A atau Pendanaan dan Investasi, terdapat $36.7 \%$ atau 11 perusahaan yang paling banyak menyajikan dengan nilai 2 dari total skor maksimal 6. Dari kategori B atau Produk dan Jasa, terdapat $23.33 \%$ atau 7 perusahaan yang paling banyak menyajikan dengan nilai 3 dari total skor maksimal 4. Dari kategori $\mathrm{C}$ atau Karyawan, terdapat 1 perusahaan yang paling banyak menyajikan, yaitu Astra International Tbk dengan nilai 7 dari total skor maksimal 10. Dari kategori D atau Masyarakat, terdapat satu perusahaan yang paling banyak menyajikan, yaitu Astra International Tbk dengan nilai 8 dari total skor maksimal 11. Dari kategori $\mathrm{E}$ atau Lingkungan, terdapat $13.33 \%$ atau 4 perusahaan yang paling banyak menyajikan dengan nilai 7 dari total skor maksimal 7. Dari kategori F atau Tata Kelola Perusahaan, terdapat $36.7 \%$ atau 11 perusahaan yang paling banyak menyajikan dengan nilai 1 dari total skor maksimal 5 .

Berdasarkan purposive sampling, terdapat dua perusahaan yang tidak memenuhi sampel, yaitu dua perusahaan yang berasal dari kelompok perusahaan yang listing di Jakarta Islamic Index (JII). Kedua perusahaan tersebut adalah PT. Charoen Pokphand Indonesia Tbk dan PT. XL Axiata Tbk. Dengan demikian semua perusahaan perbankan syariah sebanyak 11 perusahaan dan 28 perusahaan yang listing di JII yang akan dianalisis baik secara univariat maupun multivariat. 
Berikut merupakan hasil statistik deskriptif pada penelitian ini:

Statistik Deskriptif Islamic Social Reporting Index

\begin{tabular}{|c|c|c|c|c|c|}
\hline \multicolumn{6}{|c|}{ Group Statistics } \\
\hline & $\begin{array}{l}\text { Kelompok Sampel } \\
\text { Penelitian }\end{array}$ & $\mathbf{N}$ & Mean & $\begin{array}{c}\text { Std. } \\
\text { Deviation }\end{array}$ & $\begin{array}{l}\text { Std. Error } \\
\text { Mean }\end{array}$ \\
\hline \multirow[t]{2}{*}{$\begin{array}{l}\text { Pendanaan } \\
\text { dan Investasi }\end{array}$} & $\begin{array}{l}\text { Perusahaan Perbankan } \\
\text { Syariah }\end{array}$ & 11 & 4,64 &, 505 & ,152 \\
\hline & $\begin{array}{l}\text { Perusahaan yang Listing di } \\
\text { Jakarta Islamic Index (JII) }\end{array}$ & 28 & 1,39 & ,497 & ,094 \\
\hline \multirow[t]{2}{*}{$\begin{array}{l}\text { Produk dan } \\
\text { Jasa }\end{array}$} & $\begin{array}{l}\text { Perusahaan Perbankan } \\
\text { Syariah }\end{array}$ & 11 & 2,36 & 1,286 & ,388 \\
\hline & $\begin{array}{l}\text { Perusahaan yang Listing di } \\
\text { Jakarta Islamic Index (JII) }\end{array}$ & 28 & 1,86 & ,891 & , 168 \\
\hline \multirow[t]{2}{*}{ Karyawan } & $\begin{array}{l}\text { Perusahaan Perbankan } \\
\text { Syariah } \\
\end{array}$ & 11 & 5,45 & ,688 & ,207 \\
\hline & $\begin{array}{l}\text { Perusahaan yang Listing di } \\
\text { Jakarta Islamic Index (JII) }\end{array}$ & 28 & 4,82 & ,772 & , 146 \\
\hline \multirow[t]{2}{*}{ Masyarakat } & $\begin{array}{l}\text { Perusahaan Perbankan } \\
\text { Syariah }\end{array}$ & 11 & 8,00 & 2,366 & ,714 \\
\hline & $\begin{array}{l}\text { Perusahaan yang Listing di } \\
\text { Jakarta Islamic Index (JII) }\end{array}$ & 28 & 5,25 & 1,236 & ,234 \\
\hline \multirow[t]{2}{*}{ Lingkungan } & $\begin{array}{l}\text { Perusahaan Perbankan } \\
\text { Syariah }\end{array}$ & 11 & 2,36 & 2,335 & 704 \\
\hline & $\begin{array}{l}\text { Perusahaan yang Listing di } \\
\text { Jakarta Islamic Index (JII) }\end{array}$ & 28 & 4,46 & 1,934 & ,365 \\
\hline \multirow[t]{2}{*}{$\begin{array}{l}\text { Tata Kelola } \\
\text { Perusahaan }\end{array}$} & $\begin{array}{l}\text { Perusahaan Perbankan } \\
\text { Syariah }\end{array}$ & 11 & 2,00 &, 000 & ,000 \\
\hline & $\begin{array}{l}\text { Perusahaan yang Listing di } \\
\text { Jakarta Islamic Index (JII) }\end{array}$ & 28 & ,39 & ,497 & ,094 \\
\hline
\end{tabular}

Secara deskriptif, perusahaan perbankan syariah mengungkapkan indeks ISR lebih baik dibandingkan dengan perusahaan listing di Jakarta Islamic Index (JII) walaupun perbedaan di antara keduanya tidak begitu jauh. Berikutnya merupakan pengujian secara statistik dengan menggunakan Mann Whitney Test untuk berdasarkan enam kriteria; Pendanaan dan Investasi, Produk dan Jasa, Karyawan, Masyarakat, Lingkungan, dan Tata Kelola Perusahaan antar kedua kelompok sampel, yaitu perusahaan perbankan syariah dan perusahaan yang listing di JII.

Pengujian Mann Whitney Test untuk Enam Kriteria Islamic Social Reporting (ISR) Index

\begin{tabular}{|l|l|c|c|c|}
\hline \multicolumn{5}{|c|}{ Ranks } \\
\hline & $\begin{array}{l}\text { Kelompok Sampel } \\
\text { Penelitian }\end{array}$ & N & Mean Rank & $\begin{array}{c}\text { Sum of } \\
\text { Ranks }\end{array}$ \\
\hline Pendanaan dan Investasi & $\begin{array}{l}\text { Perusahaan Perbankan } \\
\text { Syariah }\end{array}$ & 11 & 34,00 & 374,00 \\
\cline { 2 - 5 } & $\begin{array}{l}\text { Perusahaan yang Listing } \\
\text { di Jakarta Islamic Index } \\
\text { (JII) }\end{array}$ & 28 & 14,50 & 406,00 \\
\hline
\end{tabular}




\begin{tabular}{|c|c|c|c|c|}
\hline & Total & 39 & & \\
\hline \multirow[t]{3}{*}{ Produk dan Jasa } & $\begin{array}{l}\text { Perusahaan Perbankan } \\
\text { Syariah }\end{array}$ & 11 & 22,82 & 251,00 \\
\hline & $\begin{array}{l}\text { Perusahaan yang Listing } \\
\text { di Jakarta Islamic Index } \\
\text { (JII) }\end{array}$ & 28 & 18,89 & 529,00 \\
\hline & Total & 39 & & \\
\hline \multirow[t]{3}{*}{ Karyawan } & \begin{tabular}{|l|} 
Perusahaan Perbankan \\
Syariah
\end{tabular} & 11 & 26,55 & 292,00 \\
\hline & $\begin{array}{l}\text { Perusahaan yang Listing } \\
\text { di Jakarta Islamic Index } \\
\text { (JII) }\end{array}$ & 28 & 17,43 & 488,00 \\
\hline & Total & 39 & & \\
\hline \multirow[t]{3}{*}{ Masyarakat } & $\begin{array}{l}\text { Perusahaan Perbankan } \\
\text { Syariah }\end{array}$ & 11 & 29,82 & 328,00 \\
\hline & $\begin{array}{l}\text { Perusahaan yang Listing } \\
\text { di Jakarta Islamic Index } \\
\text { (JII) }\end{array}$ & 28 & 16,14 & 452,00 \\
\hline & Total & 39 & & \\
\hline \multirow[t]{3}{*}{ Lingkungan } & $\begin{array}{l}\text { Perusahaan Perbankan } \\
\text { Syariah }\end{array}$ & 11 & 12,91 & 142,00 \\
\hline & $\begin{array}{l}\text { Perusahaan yang Listing } \\
\text { di Jakarta Islamic Index } \\
\text { (JII) }\end{array}$ & 28 & 22,79 & 638,00 \\
\hline & Total & 39 & & \\
\hline \multirow[t]{3}{*}{ Tata Kelola Perusahaan } & \begin{tabular}{|l|} 
Perusahaan Perbankan \\
Syariah
\end{tabular} & 11 & 34,00 & 374,00 \\
\hline & $\begin{array}{l}\text { Perusahaan yang Listing } \\
\text { di Jakarta Islamic Index } \\
\text { (JII) }\end{array}$ & 28 & 14,50 & 406,00 \\
\hline & Total & 39 & & \\
\hline
\end{tabular}

\begin{tabular}{|c|c|c|c|c|c|c|}
\hline \multicolumn{7}{|c|}{ Test Statistics ${ }^{\mathbf{a}}$} \\
\hline & $\begin{array}{l}\text { Pendanaan } \\
\text { dan } \\
\text { Investasi }\end{array}$ & $\begin{array}{l}\text { Produk } \\
\text { dan Jasa }\end{array}$ & $\begin{array}{c}\text { Karyaw } \\
\text { an }\end{array}$ & $\begin{array}{l}\text { Masyara } \\
\text { kat }\end{array}$ & $\begin{array}{l}\text { Lingkung } \\
\text { an }\end{array}$ & $\begin{array}{l}\text { Tata Kelola } \\
\text { Perusahaan }\end{array}$ \\
\hline Mann-Whitney U & ,000 & 123,000 & 82,000 & 46,000 & 76,000 & ,000 \\
\hline Wilcoxon W & 406,000 & 529,000 & 488,000 & 452,000 & 142,000 & 406,000 \\
\hline $\mathrm{Z}$ & $-5,099$ & $-1,009$ & $-2,413$ & $-3,428$ & $-2,460$ & $-5,144$ \\
\hline $\begin{array}{l}\text { Asymp. Sig. (2- } \\
\text { tailed) }\end{array}$ & , 000 & 313 & ,016 & , 001 & ,014 & ,000 \\
\hline \begin{tabular}{|l} 
Exact Sig. [2*(1- \\
tailed Sig.)] \\
\end{tabular} &, $000^{\mathrm{b}}$ &, $346^{\mathrm{b}}$ &, $024^{\mathrm{b}}$ &, $000^{\mathrm{b}}$ &, $014^{\mathrm{b}}$ &, $000^{\mathrm{b}}$ \\
\hline
\end{tabular}

Berdasarkan tabel diatas, dari enam kriteria, hanya Produk dan Jasa yang tidak signifikan. Artinya, hasil penelitian ini menunjukkan bahwa perusahaan perbankan 
syariah mengungkapkan Islamic Social Reporting (ISR) Index lebih baik dibandingkan dengan perusahaan listing di Jakarta Islamic Index (JII).

Khusus untuk kriteria Produk dan Jasa, ternyata perusahaan perbankan syariah tidak lebih baik dari perusahaan JII, tapi perlu digarisbawahi bahwa kedua kelompok perusahaan semuanya secara total tidak ada yang mendapat nol untuk kriteria ini. Jadi kedua kelompok sebenarnya cukup baik secara deskriptif, yaitu kelompok perusahaan perbankan syariah mendapat nilai 59.09\% dan kelompok perusahaan JII mendapat nilai 43.33\%. Kriteria ini terkait dengan produk yang ramah lingkungan, status kehalalan produk, kualitas dan keamanan produk, dan keluhan konsumen/indikator yang tidak terpenuhi dalam peraturan dan kode sukarela. Tentu saja, orientasi utama perusahaan, baik yang yang benar-benar beroperasi dengan konsep syariah seperti perbankan syariah ataupun perusahaan konvensional non perbankan syariah seperti perusahaan-perusahaan konvensional yang listing di JII akan lebih berfokus pada produk dan jasa.

Secara teori, JII merupakan salah satu produk pasar modal syariah di Bursa Efek Indonesia (BEI) yang menggambarkan kinerja saham syariah di Indonesia. Sahamsaham syariah yang masuk dalam JII adalah saham-saham yang sudah lulus penyeleksian kriteria dari Otoritas Jasa Keuangan (OJK) dan BEI. Perusahaan-perusahaan yang terdaftar dalam JII sudah bisa dipastikan memiliki kegiatan operasional yang tidak bertentangan dengan prinsip-prinsip syariah, sehingga besar kemungkinan banyak investor muslim ataupun pihak berkepentingan muslim lainnya yang berinvestasi dan terkait kegiatan usaha dengan perusahaan tersebut.

Berdasarkan arahan Dewan Syariah Nasional Penerbitan Efek Syariah, jenis kegiatan utama suatu badan usaha yang dinilai tidak memenuhi syariah Islam adalah usaha perjudian dan permainan yang tergolong judi atau perdagangan yang dilarang, usaha lembaga keuangan konvensional (ribawi) termasuk perbankan dan asuransi konvensional, usaha yang memproduksi, mendistribusi serta memperdagangkan makanan dan minuman yang tergolong haram, dan usaha yang memproduksi, mendistribusi dan/atau menyediakan barang-barang ataupun jasa yang merusak moral dan bersifat mudarat.

Pengkajian ulang terhadap perusahaan listing di JII akan dilakukan 6 (enam) bulan sekali dengan penentuan komponen indeks pada awal bulan Januari dan Juli setiap tahunnya, sedangkan perubahan pada jenis usaha utama emiten akan dimonitor secara terus menerus berdasarkan data publik yang tersedia. Perusahaan yang mengubah lini bisnisnya menjadi tidak konsisten dengan prinsip syariah akan dikeluarkan dari indeks JII, sedangkan saham emiten yang dikeluarkan akan diganti oleh saham emiten lain. Semua prosedur tersebut bertujuan untuk mengeliminasi saham spekulatif yang cukup likuid. Sebagian saham-saham spekulatif memiliki tingkat likuiditas rata-rata nilai perdagangan reguler yang tinggi dan tingkat kapitalisasi pasar yang rendah.

Walaupun perusahaan listing di JII melakukan praktek bisnis tanpa menentang syariah Islam, tetapi jika dikaitkan dengan pengungkapan berdasarkan indeks ISR, nilai skor yang didapatkan hanya sebesar $39.46 \%$ dibandingkan nilai skor yang didapatkan oleh perusahaan perbankan syariah sebesar $57.72 \%$. Hasil ini membuktikan secara empiris bahwa pengungkapan yang dilakukan oleh perusahaan yang benar-benar beroperasi dengan konsep syariah seperti perbankan syariah tentu ternyata memang lebih memenuhi indeks ISR dibandingkan perusahaan konvensional non perbankan syariah seperti perusahaan-perusahaan konvensional yang listing di JII.

Perusahaan perbankan syariah membuktikan penggunaan teori legitimasi bahwa kinerja suatu perusahaan memberikan pengaruh yang besar terhadap lingkungan di sekitarnya. Perusahaan perbankan syariah mampu memberikan kesan bertanggung jawab perusahaan melalui indeks ISR di dalam laporan tahunan. Dari ISR tersebut, lingkungan 
di luar perusahaan atau masyarakat dapat menilai apakah pertanggungjawaban perusahaan tersebut sudah baik atau belum. Walaupun kinerja berdasarkan indeks ISR hanya $57.72 \%$, diharapkan ke depannya akan mencapai $100 \%$.

Teori stakeholders mengatakan bahwa perusahaan bukanlah entitas yang hanya beroperasi untuk kepentingan sendiri, tetapi harus memberikan manfaat bagi stakeholders-nya. Dengan demikian, keberadaan suatu perusahaan sangat dipengaruhi oleh dukungan yang diberikan oleh stakeholders kepada perusahaan tersebut. Terdapat sejumlah stakeholders yang ada di masyarakat, jadi dengan adanya pengungkapan ISR (Islamic Social Reporting) merupakan salah satu cara terbaik untuk mengelola hubungan organisasi dengan kelompok stakeholders yang berbeda sehingga tujuan utama dari perusahaan adalah seimbang dengan konflik antara stakeholders. Dengan kata lain, pengungkapan ISR bagi suatu perusahaan bersifat penting karena para stakeholders perlu untuk mengevaluasi dan mengetahui sejauh mana perusahaan dalam melaksanakan peranannya sesuai dengan keinginan stakeholders sehingga menuntut adanya akuntabilitas perusahaan atas kegiatan ISR yang telah dilakukannya. Jadi jika para stakeholders muslim lebih suka berinvestasi pada perusahaan yang benar-benar beroperasi dengan konsep syariah seperti perbankan syariah memang sudah tepat, karena kenyataannya indeks ISR yang mengungkapkan hal-hal yang berkaitan dengan prinsip Islam, yang tercermin melalui laporan keuangan tahunannya (annual report), memang lebih tinggi nilainya jika dibandingkan perusahaan konvensional yang listing di JII.

Sebagai suatu pedoman pengungkapan, indeks ISR harus memiliki item-item yang detail dan komprehensif. Indikator-indikator indeks ISR masih sangat sederhana dan di tiap indikator mengandung makna yang luas, sehingga perlu adanya batasanbatasan agar setiap indikator dapat dievaluasi dengan baik. Jangan sampai ada peluang atau celah bahwa bahwa sebenarnya perusahaan mungkin telah melakukan sebagian besar indeks ISR, tetapi hanya tidak mengungkapkannya ke dalam laporan keuangan (annual report) saja. Padahal makin lengkap indeks ISR yang diungkapkan, makin besar peluang perusahaan dalam mempertahankan investornya dan sekaligus mendapatkan investor baru.

\section{KESIMPULAN DAN SARAN \\ Kesimpulan}

Penelitian ini membandingkan kualitas pengungkapan berdasarkan indeks ISR antara dua kelompok sampel, yaitu perusahaan perbankan syariah dan perusahaan yang listing di Jakarta Islamic Index (JII). Motivasi penelitian untuk membandingkan kedua kelompok sampel adalah untuk membuktikan apakah, pengungkapan yang dilakukan oleh perusahaan yang benar-benar beroperasi dengan konsep syariah seperti perbankan syariah tentu akan lebih memenuhi indeks ISR dibandingkan perusahaan konvensional non perbankan syariah seperti perusahaan-perusahaan konvensional yang listing di JII. Hal ini harus dibuktikan secara empiris sehingga hipotesis penelitian adalah bahwa perusahaan perbankan syariah akan mengungkapkan indeks ISR yang lebih baik dibandingkan dengan perusahaan listing di JII.

Dengan hasil survei pada laporan keuangan tahunan perusahaan perbankan syariah perusahaan, dari keseluruhan kriteria, perusahaan yang paling banyak menyajikan ISR Index adalah PT. Bank BNI Syariah dan PT. Bank Syariah Mandiri dengan nilai skor 32. Adapun perusahaan yang paling sedikit menyajikan ISR Index adalah PT. Bank Syariah Mega Indonesia dengan nilai skor 14. Secara rerata, nilai skor ISR Index untuk semua perusahaan perbankan syariah adalah 25. Secara keseluruhan jumlah skor yang dicapai kelompok ini dibandingkan dengan skor maksimal yang bisa dicapai adalah $57.72 \%$. Dengan hasil survei pada laporan keuangan tahunan perusahaan yang listing di 
JII, dari keseluruhan kriteria, perusahaan yang paling banyak menyajikan ISR Index adalah Astra International Tbk dengan nilai skor 25. Adapun perusahaan yang paling sedikit menyajikan ISR Index adalah Bumi Serpong Damai Tbk dengan nilai skor 11. Secara rerata, nilai skor ISR Index untuk semua perusahaan yang listing di Jakarta Islamic Index adalah 17. Secara keseluruhan jumlah skor yang dicapai kelompok ini dibandingkan dengan skor maksimal yang bisa dicapai adalah $39.46 \%$.

Berdasarkan hasil pengujian dengan Mann Whitney Test, hasil penelitian ini menunjukkan bahwa perusahaan perbankan syariah mengungkapkan Islamic Social Reporting (ISR) Index memang lebih baik dibandingkan dengan perusahaan listing di Jakarta Islamic Index (JII) berdasarkan kriteria Pendanaan dan Investasi, Karyawan, Masyarakat, Lingkungan, dan Tata Kelola Perusahaan, terkecuali untuk Produk dan Jasa dimana nilai perusahaan perbankan syariah dan perusahaan JII hanya berbeda tipis $15.76 \%$. Hasil penelitian membuktikan secara empiris bahwa pengungkapan yang dilakukan oleh perusahaan yang benar-benar beroperasi dengan konsep syariah seperti perbankan syariah tentu ternyata memang lebih memenuhi indeks ISR dibandingkan perusahaan konvensional non perbankan syariah seperti perusahaan-perusahaan konvensional yang listing di JII.

\section{Saran}

Keterbatasan penelitian ini hanya difokuskan pada laporan tahunan dalam mengukur sejauhmana praktek-praktek keterbukaan informasi Islam oleh perusahaan yang dipilih, menjadikan penelitian di masa depan dapat diperluas dengan memasukkan bentuk-bentuk pengungkapan seperti laporan sementara, siaran pers, pengumuman pasar saham dan pelaporan keuangan internet.

Penafsiran beberapa item ISR yang dilakukan berdasarkan interpretasi peneliti sangat subyektif. Sangat sulit untuk menemukan kata-kata yang tepat untuk menjelaskan item yang diperlukan ISR. Oleh karena itu, peneliti menyarankan agar peneliti selanjutnya menghindari subjektivitas. Metode yang lebih baik dapat diimprovisasi untuk skor yang lebih obyektif. Belum sempurnanya hasil penghitungan skor dalam penelitian ini disebabkan adanya beberapa item yang memang tidak mungkin dipenuhi oleh industri perbankan syariah atau perusahaan yang listing di Jakarta Islamic Index (JII). Oleh karena itu, perlu adanya item-item yang memang sesuai dengan kegiatan operasional perusahaan yang berorientasi menarik stakeholder penganut prinsip syariah agar setiap kriteria ISR dapat dievaluasi dengan baik.

Implikasi penelitian ini adalah agar DSN (Dewan Syariah Nasional) membuat regulasi penerapan Indeks ISR sebagai pedoman pengungkapan yang diterima secara umum di masa yang akan datang baik sebagai indeks yang berdiri sendiri atau telah dikonvergensi ke dalam indeks lainnya, maka seluruh organisasi yang melandaskan kegiatannya pada prinsip syariah di Indonesia juga harus berpedoman pada indeks ini dalam pengungkapan tanggung jawab sosialnya.

\section{DAFTAR PUSTAKA}

Ayu, D. F. 2010. Analisis Pengaruh Jenis Industri, Ukuran Perusahaan, dan Profitabilitas terhadap Tingkat Pengungkapan Islamic Social Reporting (ISR) pada Perusahaan yang Masuk Daftar Jakarta Islamic Index (JII). Skripsi Fakultas Ekonomi Universitas Indonesia. Depok.

Haniffa, R. 2002. Social Reporting Disclosure-An Islamic Perspective. Indonesia Management and Accounting Research, I, pp. 128-146. 
Maali, B., Casson, P., \& Napier, C. 2006. Social Reporting by Islamic Banks. ABACUS, 42 (2), pp. 266-289.

Maulida, A.P., Yulianto, A. \& Ansori. 2014. Analisis Faktor-Faktor yang Mempengaruhi Pengungkapan Islamic Social Reporting (ISR). Simposium Nasional Akuntansi 17. Universitas Mataram. Lombok, 24-27 September 2014.

Othman, R., \& Md. Thani, A. 2010. Islamic Social Reporting of Listed Companies in Malaysia. The International Business and Economics Research Journal. April 2010; 9, 4; ABI/INFORM Complete pg.135.

Othman, R., Thani, A.M., \& Ghani, E.K. 2009. Determinan of Islamic Social Reporting among Top Sharia-Approved Companies in Bursa Malaysia. Research Journal of International Studies 12 (10), pp.4-20.

Ousama, A. A., \& Fatima, A. H. 2006. The Determinants of Voluntary Disclosure in the Annual Report by Shariah-Approved Companies Lised on Bursa Malaysia. Paper Presented at IIUM International Accounting Conference 3, Malaysia, 2628 June 2006.

Putri, T.K \& Yuyetta, E.N.A. 2014. Faktor-Faktor yang Mempengaruhi Islamic Social Reporting Perusahaan-Perusahaan yang Terdaftar pada Indeks Saham Syariah Indonesia (ISSI) Tahun 2011-2012. Diponegoro Journal of Accounting, Vol. 3, No. 2, Hal 1153-1161.

Raditya, A.R. 2012. Analisis Faktor-Faktor yang Mempengaruhi Tingkat Pengungkapan Islamic Social Reporting (ISR) pada Perusahaan yang Masuk Daftar Efek Syariah (DES). Skripsi. Fakultas Ekonomi Universitas Indonesia. Depok.

Widiawati, S. \& Raharja, S. 2012. Analisis Faktor-Faktor yang Mempengaruhi Islamic Social Reporting Indeks Perusahaan-Perusahaan yang Terdapat pada Daftar Efek Syariah Tahun 2009-2011. Diponegoro Journal of Accounting, Vol. 1, No. 2, Hal. 248-262. 